\title{
Controlling God in The UK: The Vexed Question of Political Accountability and Faith-Based Groups
}

\author{
Dr. Adrian Barton (Corresponding author) \\ Associate Professor in Public Services Management \\ School of Management, University of Plymouth \\ Room 405b, Cookworthy Building, Drake Circus, Plymouth UK, PL4 8AA \\ E-mail: abarton@plym.ac.uk \\ Dr Nick Johns \\ Lecturer in Public Services Management \\ University of Plymouth \\ Dr. Mark Hyde \\ Associate Professor in Public Services Management \\ University of Plymouth \\ Dr. Alison Green \\ Lecturer in Social Research methods \\ School of Applied Psychosocial Studies \\ University of Plymouth \\ Greta Squire \\ Lecturer in Criminology \\ Applied Social Science, University of Brighton
}

Received: September 5, 2010

Accepted: September 20, 2010

doi:10.5539/jpl.v4n2p3

\begin{abstract}
For twelve years New Labour as the governing party of the UK was apparently obsessed with control, ensuring as far as possible that every aspect of government policy remained centrally directed. However, there was also a growth in the use and importance of third sector agencies in the delivery, and latterly, in the strategic development of, public policy. This created an implementation gap in the delivery of policy and a problem in ensuring that key policy makers from the third sector remain 'on-message'. In this paper we will demonstrate the difficulties that existed in retaining control while decentralising the delivery and development of public policy.
\end{abstract}

Keywords: Street Pastors, Governance, Evidence-based practice, Accountability

\section{Introduction}

One constant in the New Labour approach to public policy was a concern with results. Procedures were identified as secondary to the successful attainment of key policy objectives (Seldon, 2005). While this makes sense in the hidden ideology of the Third Way (Giddens, 1998), the notion of only doing 'What Works' presented a number of significant challenges from the point of view of a policy analyst. Not least, the on-going question of the implementation gap (Lipsky, 1983; Hill 2005). Latterly, we would argue that this transcended issues of delivery and actually impacted upon the development and strategic direction of policy.

In order to deal with this New Labour prioritised an evidence-based approach to policy (Wells, 2004; Pawson, 2006). Simply put, this required that working practices seen to have been successful in one geographical or organisational 
area should be rolled out to other agencies and situations. Implicit in this is the assumption that transposing practice from one area to another is merely a technical operation: for example current policy responses to child protection systems are based on the assumption that what works in one area may be applied elsewhere without reference to the existing practice base or the existing organisational and inter-personal contexts. This assumption is perhaps over-simplistic and the concept of a universal, all-encompassing 'best-practice' is contested by some professions (Barton and Welbourne, 2005).

Equally, we witnessed a drive towards 'joined-up working'. Again, on the surface this appeared to make sense, as the separation between different agencies in the welfare system created barriers to addressing what are often multi-causal social problems. Professionals working together can provide a more holistic approach to complex social problems which must be good for the client group as well as society at large. For example, in the policy area covered by this paper New Labour introduced the Crime and Disorder Reduction Partnerships in an attempt to establish a coherent response across a number of agencies in both the statutory and voluntary sectors. They emerged through the Morgan Report or to give it its full title the 'Safer Communities: The Local Delivery of Crime Prevention through the Partnership Approach (Home Office: 1991). Emphasis was placed upon 'the notion that crime prevention cannot be effectively tackled by any agency on its own, instead what is required is a holistic approach whereby effort, information, resources and expertise are shared and co-ordinated among key agencies'. Section 6 of the Act stipulated that this was to be done through an auditing system, whereby on a three-yearly cycle, all of the key statutory agencies plus others from the voluntary sector and community groups; would produce and publish a workable strategy laying-out their policies and targets for reducing crime within their geographical location.

The downside of all this was that New Labour was also wedded to centralised control (Rawnsley 2001). This paper attempts to show the paradoxical nature of the previous UK government's priorities through the lens of an evaluative study conducted in a major city in the south of England, but before the evidence is produced to illustrate this, we first need to review the means by which control has been pursued.

\section{New Labour: mechanisms of control}

It is a mistake to assume that the desire for central control is new. In fact, as we will demonstrate, successive governments have tried to achieve this. In recent political history one of the key mechanisms has been the Audit Commission. There has been a widespread perception that the Audit Commission is something new, that it is a child of the 1980s and the accompanying move toward managerialism in the public sector. In truth the Audit Commission has a history stretching back to the early 1800s. However, its recent incarnation, can be traced back to the early to mid-Thatcher period. There are numerous accounts of the impact that the Thatcher administration has had on British society and what actually fuelled her radical agenda. For our purposes we need to be aware of the reasons behind her determination to change the face of British welfare. These can be distilled into two key points: dissatisfaction with the heavily bureaucratised, professionally dominated welfare state, (which also acted as a site of political resistance to the neo-liberal inspired changes) and a determination to promote the sound stewardship of public finances (Clarke and Newman, 1997).

Looking at the former, various commentators from different political perspectives accepted that professionals had lost sight of the nature of their obligations and were seduced by individual rewards and collective control (Challis et $a l ., 1988)$. Conservative governments in this period were sceptical that left to their own devices welfare professionals would implement the drive toward a 'leaner and fitter' welfare state and to make the necessary changes to their practice and ideology. What was needed was a transition from 'welfare clients' to 'welfare consumers'.

Alongside this, there was a determination on the part of the Thatcher administration to introduce greater fiscal rigour and financial accountability. The result was that this period saw the introduction of policies which included compulsory competitive tendering, internal fragmentation of agencies into purchaser and provider units aided by the internal market and a move from the old-style explanatory and cooperative accountability to accountability based on contractual and calculative principles (Clarke and Newman, 1997). All of the above was to be monitored and evaluated by the new look Audit Commission and its remit to ensure that the three 'Es' of economy, efficiency and effectiveness dominated the management of public welfare organisations (Barton, 2002).

At the same time, there was a growing recognition that the British tradition of organising central and local government departments around service provision rather than the client group led to fragmentation and duplication. Two key reports from the 1960s (Seebohm Committee 1968 and the Redcliffe-Maude Commission 1969) called for a merger of departments to overcome this. Possibly unwittingly this approach was acted on by the Thatcher governments and as a result by the mid-to-late 1980s we saw a growth in what was then termed 'inter-agency working': as Hudson (1987) put it, by the end of the 1980s professionals working together was 'in vogue'. By the time New Labour came to power 
in 1997 audit, evaluation and joined-up working was more than just a series of linked fads, they had become combined welfare orthodoxy.

However, proclaiming to be 'New' provides an imperative to produce change and reform and 'New' Labour embarked on a further round of changes to the public sector, this time under the banner of 'modernisation'. Having re-branded and re-packaged itself as 'New Labour' the incoming government had a problem. It now had to demonstrate to both domestic and international audiences that it could be trusted to undertake its modernisation agenda. This was difficult because it had to demonstrate its distance from 'Old' Labour (for which read wedded to socialist values and in the thrall of the Trades Union Movement) at the same time as it had to show that it was not a pale blue socialist version of its neo-liberal predecessor. It attempted to do this by recourse to the Third Way. In brief this meant devising a modernisation agenda around three linked points: (i) modernisation and globalisation in which globalisation, competition and meritocracy become collapsed into a single theme; (ii) recognising the rise of sceptical consumers who become the point of accountability to the welfare providers and act as agents to improve the standard of performance from welfare services; and (iii) a switch from dogmatism to pragmatism signalling the end of ideologically driven policy toward a 'what works best' approach (Newman 2001). It is our contention that New Labour, based on its record, has been a standard bearer for the Thatcherite revolution.

To ensure that welfare professionals adhered to the Third Way modernisation agenda, under New Labour we observed an extension and growth of the external auditing process and a growth in the importance of evidence-based practice (Pawson, 2006). This charge required public sector managers to find the optimal way to ensure compliance, thus creating a form of self-regulating professional autonomy. However, self-regulation was not altogether trusted as New Labour were not averse to issuing threats and sanctions aimed at controlling the professions: some overt: 'If you are unwilling or unable to work the modern agenda, the government will have to look to other partners to take your role' (Blair, 1998); and some more subtle, none more so than the lack of praise for the public sector professionals. As Toynbee and Walker (2001: 218) note: 'Carping [about the public sector] came easier to Blairite lips than praise'.

At the same time, New Labour set about harmonising Performance Indicators (PI) across the public sector in order to ensure that organisations were able to undertake structured and therefore 'better' joined up work. However, as Newman (2001) noted, the down side of this was the creation of isomorphic approaches to social problems at the expense of professional innovation and autonomy. Arguably, this represented the lack of trust New Labour felt towards the professionals charged with implementing their Third Way vision for welfare.

To summarise, it is possible to argue that New Labour embraced and, moreover, enhanced the use of the audit and evaluation processes and evidence-based practice constructed by their Conservative predecessors in order to ensure that the political aims of New Labour were met by those charged with the delivery of policy. It seems equally clear that New Labour had little trust in the ability or desire of those tasked to deliver welfare to be able to achieve this by their own volition hence the growth in external audit and the use of threats and coercion to ensure compliance. Accordingly, New Labour used the seemingly technical audit and evaluation process as a transformative tool (Barton, 2005) to ensure that professionals adhered to policy by undermining, or at the very least curbing professional autonomy.

While this has proven relatively straightforward in terms of statutory agencies, the growth of third sector input into policy delivery and development has created a greater challenge. To illustrate this we will draw on work conducted in the south of England evaluating a Street Pastor initiative. In the first instance it is necessary to outline the genesis and growth of this movement before going on to use their example to illustrate how in a public policy environment driven by central control an organisation can thrive and operate without accountability and a sufficiently robust evidence-base.

\section{The genesis and growth of the Street Pastor movement}

The Street Pastor project was set up in the UK through the Ascension Trust, which was established in 1993 by Reverend Les Isaacs and colleagues in response to the multi-layered deprivation they saw in British society: economic, social and spiritual deprivation. The original work of the Ascension Trust centred around gang-related gun crime in inner city London. Reverend Isaacs visited Jamaica in 2001 to investigate church-led strategies with disaffected youth involved in gangland culture. This investigation provided the impetus to set up the Street Pastor initiative as a model adapted from the Jamaican experience. A year later The Ascension Trust launched a project in Brent, Hackney, Haringey, Lambeth and Southwark in London; shortly afterwards similar efforts were made in Aston in Birmingham, and inner city Moss Side and Longsight in Manchester. The project was called the 'Guns of our Streets' tour. The overall aims of the tour were to raise awareness of gun crime, to generate practical ways to implement policy to reduce gun crime, to build community relations between the church and the non-church community and to encourage a multi-agency approach to dealing with gun-crime in each of the given areas. From 
this a report was written as a result of consultations and discussions, which led to the setting up of the Street Pastor project in January 2003.

The Street Pastors constitute an inter-denominational response to neighbourhood problems that seeks to offer practical solutions to immediate problems - not through preaching but through activity. The Street Pastors use outreach methods to engage with disenfranchised young people and others. Individuals wishing to join have to satisfy pragmatic and spiritual criteria. In terms of the former each person has to pass a Criminal Records Bureau (CRB) check in order to proceed. The second is that recruits to the Street Pastor movement have to be people with a deep faith and a religiously-inspired desire to offer practical help within their communities. In this way, Street Pastors accommodate the practical needs of the secular world and the faith related needs of the religious domain. A twelve week training programme has to be negotiated and then, depending on their location, individuals graduate in a formal ceremony. Ultimately they patrol the streets at night, often in the night-time economy (NTE), and can be identified by their uniform of jackets or polo shirts and baseball caps or woolly hats (seasonally determined).

The growth of the Street Pastors has been remarkable. By the end of 2009 there were more than 3,000 individual Street Pastors in the UK, working in over 100 projects. These stretch from Aberdeen in Scotland to Camborne in the far south west of England (McGuinness, 2009: 20). It is important to note that whilst the Street Pastors work under the umbrella of the Ascension Trust there is a great deal of local autonomy and arguably any democratic scrutiny of this movement should take place at the local level as it is at this level where agreement to accept the Street Pastors is negotiated.

The Street Pastors' mission statement is as follows, to provide an 'interdenominational response to neighbourhood problems; engaging with people on the streets and in night-time venues to, listen, dialogue and offer practical help and solutions'. Their expressed values are as follows:

- $\quad$ The sacredness and sanctity of human life;

- Valuing and honouring the community;

- $\quad$ Taking personal responsibility;

- $\quad$ Being a person of integrity;

- The growth and development of the person to their fullest potential.

Drawn from these values they have two stated aims:

- $\quad$ To develop the project to build capacity and sustainability, and;

- To provide an outreach volunteer service to prevent crime, defuse volatile situations and divert those involved and/or at risk of criminal activity and anti-social behaviour into training, employment and other meaningful and empowering pursuits. (Select Committee on Home Affairs, 2006).

One thing to note is the way in which the original rationale for Street Pastors has been transcended. In the first instance it was designed to tackle the problem of gun crime and this mainly amongst the African-Caribbean community in the UK. What we now have is an organisation that seeks to provide wide-ranging welfare oriented interventions on the streets with 'anti-social behaviour' in mind, most notably the 'malevolence of binge-drinking'.

This expansion of their remit is important because it carries serious implications for issues that relate to New Labour's policy agenda as set out above; in particular, the location of third sector organisations in a culture of control. We will set out the details of this in presenting the findings, and flesh them out in the discussion section below. First it is necessary to explain the basis for the empirical claims made in this paper.

\section{The study}

The data in this paper comes from a two part project conducted in a major city in the south of England. The first part of the study was a feasibility study aimed at assessing whether an existing Street Pastor group could and should be moved into a higher risk area of the city's NTE. The second phase, conducted some six months later, was an impact assessment of that move. It was commissioned by the local police in concert with the Street Pastors. Before we talk about the project and its findings in more detail it is worth locating the project in the wider material relating to Street Pastor movement more widely.

In the local initiative recruits come to the programme through their churches as either nominees or volunteers. They pay a $£ 300$ fee to enrol which covers training and the cost of the uniform. The training, as stated above, includes a twelve week programme which has components on sociology, criminology and theology as well as more practical matters such as first-aid and self-defence. Although recruits can accompany patrols before their training is complete, they cannot formally become Street Pastors until it is successfully completed.

At the time of the research, the patrols were made on Saturday nights between the hours of 10pm and 4am, the Street Pastors were split into two teams covering separate areas. Each patrol consisted of between 2-4 people and 
they were supported via radio link with a prayer group based back at the church offering advice, support and prayer. The patrols not only engage with people on the streets they also make a point of building relationships with shopkeepers, door staff, takeaway proprietors and publicans. The published aims of the Street Pastor group in the research are:

- $\quad$ As a 'presence' ministry from the Christian churches ('the church has left the building');

- $\quad$ As a visible presence to reassure folk who may feel vulnerable;

- To help reduce the (alarming) fear of crime that far outweighs the actual reality of the situation;

- To be a listening ear to the lonely, the vulnerable, the frightened, the intimidated, the hurting....;

- $\quad$ And to offer genuine, non-judgemental pastoral support to those who request help.

The first part of the research took the form of a viability study combined with an informal evaluation stretching over a three month period, from December 2008 to January 2009 and the second part took place in July 2009. The research involved a multi-method approach employing documentary analysis, observations, informal and semi formal interviews and an unstructured focus group. Observations were made of the training sessions provided to the Street Pastors and the authors actually accompanied patrols to see firsthand how they operate. The semi-formal interviews were completed with the Director of the Street Pastors and the training co-ordinator, also with an Inspector within the Police who was involved with the setting up and management of the project. These people were re-interviewed in the second phase with additional interviews taking place with key stakeholders in the Local Authority.

The informal interviews were carried out on two separate evenings the first of which involved door staff in the area. Eight pubs and clubs took part and thirteen staff members. The second round of interviews was conducted with takeaway and restaurant owners in nine establishments. Finally, an unstructured focus group was organised with homeless people (ranging from street drinkers to rough sleepers) whilst helping out at a Christmas dinner organised by one of the Police Community Support Officers. Again, in the second phase, the same groups were re-interviewed.

\section{Findings}

Several themes emerged from both phases of the research work but for the purposes of this paper we are concentrating on issues of evidence and democratic accountability. Before doing that however, we need to provide evidence of the vision and long-term goal of the Street Pastor movement in our city. This is best done in the words of a key Street Pastor actor:

I hope to see a city that values its neighbourhoods, and partying, and commercial and family, and ethnicity and cultural life in a whole higher way, in a less selfish way, and in a way that allows a for a more corporate image across the City. This is a massive statement and would imply that there isn't that at the moment. I believe there isn't that at the moment, the City has a very self-centred attitude, and within society generally. I want to see people start valuing human life, not taking things for granted, not sticking their heads in the sand when things get tough, a lot less addiction - alcohol, which is the key drug at the moment here - and with a little bit more sensibility. I think there is a spiritual inquiry generally, may not be Christian, or Islam, but a spiritual inquiry nonetheless, where can you ask the questions, the fact we are out on the streets and not hidden - we are just there. It gives people permission to bring out their spiritual inquiry in a non-threatening way on their own turf (Street Pastor Co-ordinator).

Clearly, the SPs have an agenda for change that not only covers the physical nature of the NTE but also, long-term, seeks to change the spiritual nature of the NTE and the city as a whole. This resonates in central government policy (Lowndes and Chapman, 2005).

Arguably such a vision ought to be based on a strong evidence-base, yet such a base seemingly does not exist. As part of the research we did a comprehensive literature review and could find only one other published evaluation of a Street Pastor scheme (more of which below) (Cornish, 2009). Beyond that, we could only find a variety of media reports some of which were in independent outlets and some of which were in Church-based publications (McGuinness, 2009). In a period where the government is clearly wedded to evidence-based practice we would suggest that at best this is anomalous with current policy, and at worst rides rough shod over the lived reality of other providers of welfare services. This lack of evidence was raised in the interviews with key actors in the local CDRP.

When asked whether there had been any feedback on the efficacy of the Street Pastors locally, or any other evidence, the Leader of the Council said:

Yes, I've talked to some of the security men down there, because some of them we hire for our events. And I say you think the SPs are doing a good job? And they think they're doing a brilliant job, because if someone is too 
drunk they're not allowed in the clubs and they're out on the pavement so they could be a nuisance. They're trying to get into the club or whatever, and the SPs will talk to them and calm them down and they'll go on their way. And they are a help down there there's no doubt about it.

Similarly, the nature of the available evidence was reiterated by other respondents:

The bits of work that I hear of that they do are mainly through police reporting and going to police groups where they will report what the Pastors are doing. And the aspects of the evening or NTE that they want them to be looking at. They are discussed more at police meetings than partnership meetings... I struggle with the fact that it's all a bit anecdotal really. I think the police have got a huge target on public confidence haven't they? And obviously we've got them to reduce fear of crime. But how you measure that is really the challenge isn't it? (Community Safety Officer 2).

I know that [the Chief Inspector] paid for a celebration event recently [for the SPs] just to sort of congratulate them on the things they've been doing, but I don't know. I find that quite difficult to understand what it is we're celebrating, because we don't really know the impact they're having other than that they do good work. For me I'd rather have done something post-evaluation where we could have said because of the SPs this has happened, this has changed, that's different people feel safer whatever. There's no harm in supporting people out there doing good work but I don't feel we're ready to celebrate quite yet because I don't know what it is we're celebrating (Head of Community Safety Unit).

What was apparent was the strength of the police involvement locally:

So it was almost, and being the age I am I'm very cynical of course. I used to think well what's going on here? Because actually there's always a named police officer who always seems to admit that they are a member of this church where the SPs are now all of a sudden you've got the SPs (Community Safety Officer 1).

To summarise then, there is an absence of evidence to support the impact of Street Pastors in the city, but despite this they are being encouraged to expand their services. This has been almost entirely driven by the police, and it is this issue, in the context of multi-agency working that leads neatly onto our second point.

Our concern here was the place, or otherwise, that the SPs occupied in the local strategic milieu. For an organisation that has rapidly become central to the control of the NTE the SPs have circumvented any formal structures. The only input into the wider strategic development of the city's community safety plan have been regular slots at community focus weeks, which amounts to running a stall at an event designed to assuage community fears by providing information to the general public, and, a single instance of information gathering on behalf of the community safety unit.

...we didn't send them out there to spy on people or anything. It's an area that they usually go to anyway but we actually asked them specifically if they could really concentrate on those two, on that area for those two nights, just to get a feel of just how bad the area was. Short of actually going out myself... And it is a difficult one, you know they're recognised and well know in that area now anyway. They're not the police so it was actually really good opportunity for us to get somebody unbiased to kind of go out and get a flavour of exactly how bad it was. You know, because when people are reporting crime there is a propensity to make it seem worse than it really is, and then I got a report back, which is a report about the whole week so there's comments. We set up a kind of community focus week HQ which was based at the [local] Hall so that all the agencies can kind of set up information, people, members of the community can just wander in off the street and just pick up information, make contact with people and that kind of thing. And they come to that as well [the Street Pastors] (Community Safety Officer 1).

Again we raised the seeming lack of engagement in joint-working structures with key actors in the formal community safety system and the following quotes provide an indication of this lack of engagement:

Very much so made by them [the parameters of Street Pastors strategic involvement]. And that is their choice and I think almost rightly so. We can work alongside them, or they can work alongside us, that sounds really arrogant! We know they're there and we would call upon them, and this is about, as I say linking them into community action weeks, getting those people on board. And this isn't a spying thing i mean they're out in Mutley so let's join together. But no they don't have a policing role and I don't think they should have a policing role (Community Safety Officer 1).

Furthermore, the nature and extent of their involvement in the strategic framework in terms of community safety is determined by them. So while they are a key and growing part of the city's NTE, sold largely on the basis of their community safety impact, they remain outside any formal policy infrastructure. 
The research indicates that for some senior members of the SP organisation incorporation into formalised processes and groups represents a substantial threat to their organisational identity and vision:

The thing is I think its strength is its informality. Its independence. Because the one thing we do not want is to be put in a situation where we are, for want of a better word, dictated to. The ethos of SPs is very much governed by our faith first and foremost. Consequently we wouldn't want to be put in a situation where, for example, let's say we were talking about funding, where we were fundamentally reliant on one source of funding and they came along and said we will carry on this funding stream but you're going to have to change your ways, or you'll have to do something differently. I don't think that would sit very comfortably (Chair of SP Board).

However, it was evident from the material gained from the community safety professionals that this lack of engagement prevents fully informed strategic planning:

We would like to have them reporting in some way, this is the number of people we've supported Friday and Saturday night. This is the number of people we got home safely, the number of people we issued flip flops to. All those sorts of things... (Head of Community Safety Unit).

There was no feedback mechanism into the CDRP at all, and it became clear that although the Community Safety Unit had provided funding for the first phase of the research, we as the research team had not be informed, and they had never seen the interim report.

A key issue for the research involved exploring whether an alternative secular organisation would be allowed to operate and develop in a similar way. It was apparent that there were mixed views about this amongst respondents.

I think the SPs are actually trying to grow to go outside of [the NTE] and into other areas, I think they're trying to do that themselves. They just need to go out and get more volunteers and that will happen. But I don't know about anybody else, because the SPs they have this very sort of calming, you know they're not like vigilantes. I wouldn't want people to think that if a group came up somewhere else in the town that they're a bit like vigilantes (Leader of the Council).

On the other hand:

I think this comes back to my point about where do the Pastors fit with the formal structure? And this is my point. The Pastors are one group, but you could have a group in any area that forms into that sort of we're helping in our area kind of group, and then it's just yet again back down to what can they do to help us reduce crime? And if they come and prove they can reduce crime then we are going to support them in their efforts. I don't see anything wrong with that myself (Community Safety Officer 2).

However, one thing that was consistent was the belief that the SPs, as a religiously derived organisation are inherently good and therefore trustworthy:

I don't think for one moment that people down in [the $\mathrm{N}$ areas] or anywhere else think of them as religious. I don't think they think of them as that. They think they're just a nice group of people coming along having a chat, and they never, ever, and they are very strict on this, they never make judgements on anybody (Leader of the Council).

But then they're doing it from maybe a different perspective from somebody who isn't a member of church, who has this. It is about caring or whatever. They are just very caring people, and they're all lovely. But actually the ethos of it is care, pastoral care (Community Safety Officer 1).

While most respondents were eager to underline the fact that SPs do not preach and that they go to great lengths to distance themselves from public expressions of faith (unless approached on this basis), it was clear that faith is the decisive factor in explaining the growth and influence they have had in the city.

\section{Discussion}

The birth and growth of the SP movement chimes with many of the public policy priorities espoused by New Labour in office. Some of these are overt and others less so. From the point of view of explicit policy objectives they clearly satisfied the aim to promote the third sector as a major provider of public policy (Cabinet Office/Treasury, 2007). The stranglehold of the public sector on deciding on priorities and delivering policy, whereby Blair labelled them as the forces of conservatism (Rawnsley, 2001), has been effectively broken. The third sector is now woven very firmly into the warp and weft of delivery and policy strategy.

They also fit, on the surface at least, with the multi-agency agenda identified above. They are fundamentally entrenched in the management of the NTE in a growing number of locations across the British Isles. Not only in cities with perceived issues around anti-social behaviour, but in smaller urban environments and even the most remote rural areas. 
On a less explicit note, the SPs also appear to resonate with the often unstated Christian Socialist ideals that were very obvious during Blair's occupation of the premiership. Under Brown this became less apparent, but with his particular background as the son of a Scottish Minister, it would perhaps be surprising if Christianity were absent from his political worldview: 'Brown has none of [Blair's overt religious] tone, but his politics are shaped as much by his background...as Blair's' (Naughtie, 2002: 280; see also Lowndes and Chapman, 2005). Thus in many ways, both overtly and less explicitly the SPs ticked many of the public policy requirements of New Labour.

However, as we have seen there are other equally important areas where they seemed to contravene New Labour's agenda. On the one hand, certainly in the city in which we conducted our research, while they do co-operate with key agencies - most notably with the police - they are not formally part of any strategic framework. As far as we could ascertain the sole formal requirement of them is that they have to comply with the Standard Operating Procedures laid down by the Police service. This means that despite the huge support they have from the key agencies involved in controlling the NTE, they are entirely unaccountable. As the head of community safety said above, they ought to have a stronger association with the local CDRP, but they do not, and there seems no impetus at the moment to change this situation. The lack of accountability runs deeply through the movement, as any problems encountered by the SPs either as individuals or as an organisation are dealt with internally - for example disciplinary matters or risk assessment processes. Essentially this means that an organisation that has grown rapidly in the past 6 years, and which now has a substantial part to play in the NTE and its management is largely externally unaccountable.

Again audit and evaluation were cornerstones of New Labour thinking and policy and the focus on evidence enabled them to promote themselves as the anti-ideological, 'what works' party in government. And yet, as shown above there is no real evidence-base to support key public policy developments in the third sector, such as the work of the SPs. Many claims have been made, such as the fall of violent crimes in patrol areas (Norfolk Street Pastors, 2009), but the hard data does not exist to support this. Statistics are being used in ways they really ought not to be. Their rise fails to fit the centralised control model outlined above: to date we are aware of only two evaluations carried out in the UK. Our own and one produced recently in Portsmouth by a Public Health Practitioner Trainee (Cornish 2009). The Portsmouth evaluation arguably lacks any real critical appraisal. If the SPs are to expand further, both geographically and in terms of the scope of their work, there has to be a drive towards a full-scale, independent evaluation carried out nationally.

At a time when transparency and accountability were seen to be paramount in public policy, and evidence drives the agenda, the SP phenomena is somewhat puzzling. However, there is a very clear reason, we would argue, why this has been allowed to happen. The religious component of their work, while not explicit, provides the SPs with a cloak of implied goodness. When we asked key actors whether a secular body would be given the same support and resources, the answer was mostly the same: they would be seen as vigilantes. And this fits with the known history of this subject. In the early 1990s Michael Howard, the then Home Secretary, proposed that citizens should reclaim the streets by walking with purpose, at that time it was vigorously opposed by the police and by New Labour in opposition (Goodwin, 2004; Joyce 2006). Consequently, it seems that government policy under New Labour applied only selectively to those groups unable to promote themselves as moral leaders, and that this moral leadership appeared to be entirely self-defined, or conveyed by widely held public assumptions.

\section{Conclusion}

New Labour was arguably obsessed with maintaining control over their welfare reform agenda. In this context professionals in welfare settings were subject to constant audit, a requirement to evidence their actions, and to work as holistically as possible. However, third sector organisations were clearly not always expected to provide evidence for their performance, or, play a part in the strategic frameworks in their local areas depending on their motives and orientation. In this paper we have presented evidence to suggest that while the SP initiative fit well with certain demands of New Labour policy, they grew both geographically and in terms of the scope of their work despite an absence of evidence and with virtually no accountability. We would argue that a full-scale evaluation into their work is urgently required, both to protect their organisation and to remain consistent with governmental policy. If anything the election of a Conservative-Liberal Democrat Coalition set on instituting the 'Big Society' where third sector providers are promoted even further makes this even more urgent. Faith alone cannot stand as justification for taking responsibility for service provision in a public policy context that continues to be driven by evidence and accountability.

\section{References}

Barton, A. (2002). Managing fragmentation: An Area Child protection Committee in a time of change, Aldershot: Ashgate. 
Barton, A. (2005). Working in the margins: Shadowland agencies, outreach workers and the crime audit process, Drugs: Education, Prevention, and Policy, 12 (3): 239-246. doi:10.1080/09687630500083576, http://dx.doi.org/10.1080/09687630500083576

Barton, A. (2009). Controlling practice: New Labour's management, audit and 'what works' approach to controlling the 'untrustworthy' professions, in Johns, N.R. \& Barton, A. (eds). Evaluating the Political Achievement of New Labour Since 1997: Social Policy and Public Trust, New York: Edward Mellen Press.

Barton, A. \& Johns, N.R. (2005). Pragmatism and the Third way: an Open door to New Racism?, Social Policy and Society, 4 (3).: 283-291. doi:10.1017/S147474640500240X, http://dx.doi.org/10.1017/S147474640500240X

Barton, A. \& Welbourne. P. (2005). Context and its significance in identifying 'what works' in Child Protection, Child Abuse Review, 14: 177-194. doi:10.1002/car.892, http://dx.doi.org/10.1002/car.892

Cabinet Office/Treasury (2007). The future role of the third sector in social and economic regeneration: Final report, London: HMSO.

Carr, S. (2008). Sexuality and religion: A challenge for diversity strategies in UK social care service development and delivery, Diversity in Health and Social Care, 5 (2): 113-122.

Challis, L., Fuller, S., Henwood, M., Klien, R., Plowden, W., Webb, A., Whittingham, P. and Winstow, G. (1988). Joint Approaches to Social Policy: Rationality and practice, Cambridge: Cambridge University Press. doi:10.1017/CBO9780511598333, http://dx.doi.org/10.1017/CBO9780511598333

Clarke, J. and Newman, J. (1997). The Managerial State, London: Sage.

Bowpitt, G. (1998). Evangelical Christianity, Secular Humanism and the Genesis of British Social Work, British Journal of Social Work, 28: 675-63

Colebatch, H.K. (2002). Policy (2 ${ }^{\text {nd }}$ ed). Open University Press: Maidenhead.

Cornish, P. (2009). Evaluation of the Street Pastors Initiative in Portsmouth, Portsmouth: South Central Strategic Health Authority.

Doward, J. (2008). Church attendance 'to fall by 90\%', The Observer, 21/12/08, http://www.guardian.co.uk/world/2008/dec/21/anglicanism-religion.

Duffy, J. (2002). Return of the 'Guardian Angels, BBC News Online, http://news.bbc.co.uk/1/hi/uk/2317109.stm.

Easton, D. (1953). The Political System, Knopf: Chicago.

Fraser, D. (2002). The Evolution of the British Welfare State (3rd ed), London: Palgrave.

Giddens, A. (1998). The Third Way. The Renewal of Social Democracy, Oxford: Polity.

Goodwin, S. (1994). Labour in Blackpool: Prescott attacks 'despicable lying Tories', The Independent, http://www.independent.co.uk/news/uk/labour-in-blackpool-prescott-attacks-despicable-lying-tories-1441565.html.

Hill, M. (2005). The Public Policy Process (4th ed), Pearson Education: Harlow

Hoffman, J.P. (1998). Confidence in religious institutions and secularization: Trends and implications, Review of Religious Research, 39 (4): 321-343. doi:10.2307/3512442, http://dx.doi.org/doi:10.2307/3512442

Hudson, B. (1987). Collaboration in Social Welfare: a framework for analysis, Policy and Politics, 15 (3): 175-182. doi:10.1332/030557387782455164, http://dx.doi.org/10.1332/030557387782455164

Joyce, P. (2006). Criminal Justice: An Introduction to Crime and the Criminal Justice System, Devon: Willan.

Lipsky, M. (1983). Street-Level Bureaucracy: Dilemmas of the Individual in Public Service, New York: Russell Sage Foundation.

Lowndes, V. and Chapman, R. (2005). Faith, hope and clarity: Developing a model of faith group involvement in civil renewal, Local Governance research Unit: De Montfort University: Leicester

McGuinness, J. (2009). Walking the streets with the flip-flop angels, Church Times, 30/1/09: 20-21.

Moss, B. (2005). Spirituality and Religion, Lyme Regis: Russell House Publishing.

Moss, B. and Thompson, N. (2006). Spirituality and Equality', Social and Public Policy Review, 1 (1), http://www.uppress.co.uk/socialpolicy_pdf/Thompson.pdf.

Naughtie, J. (2002). Rivals: Blair and Brown the intimate story of a political marriage, London: Fourth Estate.

Newman, J. (2001). Modernising Governance: New Labour, Policy and Society, London: Sage. 
Nieman Reports (2003). Investigating Scandals in the Catholic Church, 57 (1): 52.

Norfolk Street Pastors (2009). Pastors help reduce crime on Norwich streets, http://www.networknorwich.co.uk/Articles/87048/Network_Norwich_and_Norfolk/Partners/Street_Pastors/Street_P astors_Archive/Pastors_help_reduce_crime_on_Norwich_streets.aspx.

Pawson, R. (2006). Evidence-Based Policy: A Realist Perspective, London: Sage.

Rawnsley, A. (2001). Servants of the People: The inside story of New Labour, Penguin: Harmondsworth.

Seldon, A. (2005). Blair, London: Free Press. doi:10.1017/CBO9780511490804, http://dx.doi.org/10.1017/CBO9780511490804

Shupe, A. (1997). Vicissitudes of public legitimacy for religious groups: A comparison of the Unification and Roman Catholic Churches, Review of Religious Research, 39 (2): 172-183. doi:10.2307/3512181, http://dx.doi.org/10.2307/3512181

Thane, P. (1996). The Foundations of the Welfare State (2 ${ }^{\text {nd }}$ ed.), London: Longman.

Toynbee, P. and Walker, D. (2001). Unjust Rewards: Ending the Greed That is Bankrupting Britain, London: Granta.

Wells, P. (2004). New Labour and Evidence Based Policy Making, Paper presented to the Political Economy Research Centre Research Seminar, 16th May 2004.

Wilkes, D. and Sears, N. (2009). Persecuted for praying: Nurse who faces the sack after offering to pray for sick patient', Mail

Online,

http://www.dailymail.co.uk/news/article-1133423/Nurse-faces-sack-offering-pray-sick-patient.html.

Wright S.G. (2002). Dying to Take Care of You, Royal College of Psychiatrists, Spirituality Special Interest Group, Newsletter No.7.

Zohar, D. and Marshall, I. (2004). Spiritual Capital: Wealth We Can Live By, London, Bloomsbury. 